Marek Mrówczyński

marekmr@ukw.edu.pl

orcid.org/0000-0003-3614-2628

Uniwersytet Kazimierza Wielkiego w Bydgoszczy

Instytut Prawa i Ekonomii

pl. Weyssenhoffa 11

85-072 Bydgoszcz

\title{
Administracyjna i sądowa egzekucja z ruchomości o wartości historycznej, naukowej lub artystycznej
}

\author{
Administrative and judicial execution against movables \\ possessing historical, scientific or artistic value
}

\begin{abstract}
Summary: This article analyses specific regulations regarding the administrative execution against movables possessing historical, scientific or artistic value and judicial execution against movables possessing historical or artistic value. Such considerations are even more necessary taking into account the recent changes made to regulations regarding administrative execution, which came into force in 2020. The expressions "movables having a historical, scientific or artistic value" and "movables having a historical or artistic value" are not identical to that of monuments, which have their own legal definition in Polish law. However, the phrases imply the presence of a monument. The distinctive features of these regulations regarding the assessment, transfer and sale of the objects in question do not aim to create a specific legal regime protecting objects of this kind from administrative or judicial execution. Their purpose is to ensure the correctness of related acts and the efficiency of the execution itself. It is important that legislators do not exclude the application of ordinary forms of sale for the objects in question; i.e., they are subject to regular forms of commerce.
\end{abstract}

Keywords: administrative execution, judicial execution, movable, monument, execution against movables, artistic value, historical value, scientific value 


\section{ARTYKUEY}

Marek Mrówczyński

Streszczenie: Opracowanie poświęcone jest przepisom szczególnym w zakresie egzekucji administracyjnej z ruchomości o wartości historycznej, naukowej lub artystycznej i w zakresie egzekucji sądowej z ruchomości o wartości historycznej lub artystycznej. Rozważania na ten temat są tym bardziej potrzebne $w$ obliczu nowelizacji tych przepisów dotyczących egzekucji administracyjnej, która to nowelizacja weszła w życie w 2020 r. Sformułowania "ruchomość o wartości historycznej, naukowej lub artystycznej” i „przedmiot o wartości historycznej lub artystycznej" nie są tożsame z pojęciem zabytku, mającym swoją legalną definicję w polskim prawie. Niemniej pojęcia te obejmują sobą węższe pojęcie zabytku. Odrębności zawarte $w$ tych przepisach szczególnych, a dotyczące szacowania, dozoru i sprzedaży, nie mają na celu stworzenia reżimu prawnego chroniącego przedmioty tej kategorii, w tym zabytki, przed egzekucją. Zmierzają natomiast - ze względu na specyfikę tych przedmiotów - do zapewnienia prawidłowości czynności egzekucyjnych i usprawnienia egzekucji. Istotne jest, że ustawodawca nie wyłącza w stosunku do tych ruchomości zwykłych sposobów sprzedaży, tzn. możliwa jest sprzedaż na zasadach ogólnych.

Słowa kluczowe: egzekucja administracyjna, egzekucja sądowa, ruchomość, zabytek, egzekucja z ruchomości, wartość artystyczna, wartość historyczna, wartość naukowa

\section{Uwagi wprowadzające}

Skierowanie egzekucji do ruchomości może mieć miejsce $w$ dwóch całkowicie różnych sytuacjach ${ }^{1}$. Ze względu bowiem na kryterium rodzaju obowiązku podlegającego wykonaniu odróżnić należy egzekucję wydania ruchomości (egzekucję odebrania rzeczy ruchomej) od egzekucji z ruchomości. Na gruncie egzekucji sądowej² pierwszy z wymienionych wypadków należy do szerszej kategorii egzekucji świadczeń niepieniężnych; w drugim wypadku chodzi o inny rodzaj egzekucji sądowej, a mianowicie egzekucję świadczeń pieniężnych. Egzekucja świadczenia pieniężnego może być prowadzona właśnie m.in. z ruchomości. Taka egzekucja polega na zajęciu ruchomości (stanowiącej co do zasady własność dłużnika) i jej spieniężeniu

1 Por. Z. Merchel, Ruchomość jako przedmiot egzekucji. Postępowanie, wzory pism i orzeczeń, Currenda, Sopot 2006. Ruchomości - wraz z nieruchomościami - tworzą w prawie cywilnym kategorię rzeczy. Ruchomością jest każda rzecz, która nie stanowi nieruchomości; Z. Radwański, Prawo cywilne - część ogólna, C.H. Beck, Warszawa 2007, s. 119.

2 W Kodeksie postępowania cywilnego (ustawa z dnia 17 listopada 1964 r. - Kodeks cywilny, tekst jedn. Dz. U. z 2019 r., poz. 1460 ze zm.; dalej: k.p.c.) egzekucja sądowa jest uregulowana w dziale I tytułu II części trzeciej w art. 844-87911. 
Administracyjna i sądowa egzekucja z ruchomości o wartości historycznej... Administrative and judicial execution against movables possessing historical...

w celu zaspokojenia wierzyciela (egzekucja ta przebiega więc przez dwa etapy3). Tak samo rozumiana egzekucja z ruchomości występuje na gruncie regulowanego ustawą z dnia 17 czerwca 1966 r. $^{4}$ postępowania egzekucyjnego $\mathrm{w}$ administracji5; jest tu ona jednym z możliwych środków prowadzenia egzekucji obowiązków pieniężnych (należności pieniężnych) ${ }^{6}$, którą odróżnić należy od egzekucji obowiązków niepieniężnych?.

Opracowanie niniejsze dotyczy egzekucji z ruchomości - zarówno administracyjnej, jak i sądowej - ma na celu przeanalizowanie szczególnego wypadku egzekucji z ruchomości. Takiego mianowicie, w którym ruchomość ma pewne szczególne właściwości, sprawiające, że podlega specjalnemu reżimowi prawnemu. Niektóre bowiem rzeczy mogą reprezentować sobą pewną szczególną wartość - w tym ze względu na znaczenie dla dziedzictwa i rozwoju kulturalnego - i mieć z tego powodu w prawie odrębny status. W polskim systemie prawnym ogólnymi przepisami ustanawiającymi specjalny reżim prawny dla kategorii przedmiotów o szczególnym znaczeniu dla dziedzictwa i rozwoju kulturalnego są przepisy ustawy z dnia 23 lipca 2003 r. o ochronie zabytków i opiece nad zabytkami (dalej u.o.z.) $)^{8}$. Zgodnie $z$ art. 3 pkt 1 u.o.z., zabytek to nieruchomość lub rzecz ruchoma, ich części lub zespoły będące dziełem człowieka lub związane z jego działalnością i stanowiące świadectwo minionej epoki bądź zdarzenia, których zachowanie leży w interesie społecznym ze względu na posiadaną wartość historyczną, artystyczną lub naukową. Ustawa wprowadza ograniczenia dotyczące prawa własności zabytków ${ }^{9}$; co do zasady nie jest natomiast reglamentowany obrót zabytkami. W jakim zakresie

3 Zob. A. Marciniak, Postępowanie egzekucyjne w sprawach cywilnych, Lexis Nexis, Warszawa 2005, s. 198. Ewentualnie występującym trzecim etapem jest podział sumy uzyskanej z egzekucji (zob. Z. Woźniak, Egzekucja świadczeń pieniężnych, w: J. Gołaczyński (red.), Wybrane zagadnienia egzekucji sądowej, Wolters Kluwer Polska, Warszawa 2008, s. 194).

4 Ustawa z dnia 17 czerwca 1966 r. o postępowaniu egzekucyjnym w administracji, tekst jedn. Dz. U. z 2019 r., poz. 1438 ze zm. (dalej: u.p.e.a.).

5 Zob. W. Piątek, A. Skoczylas, Postępowanie egzekucyjne w administracji, w: Hauser R. (red.), System Prawa Administracyjnego, t. 9, Hauser R., Niewiadomski Z., Wróbel A. (red.), Prawo procesowe administracyjne, Warszawa 2020, Legalis, nb 396. Por. P. Przybysz, Egzekucja administracyjna, Dom Wydawniczy ABC, Warszawa 1999, s. 172-173; zob. rozdział VI działu II, art. 97-109 u.p.e.a.

6 W. Piątek, A. Skoczylas, op. cit., nb 396; K. Chorąży, w: K. Chorąży, W. Taras, A. Wróbel, Postępowanie administracyjne, egzekucyjne i sadowoadministracyjne, Wolters Kluwer Polska, Warszawa 2009, s. 224-225; M. Szubiakowski, w: M. Wierzbowski (red.), Postępowanie administracyjne - ogólne, podatkowe, egzekucyjne i przed sadami administracyjnymi, C.H. Beck, Warszawa 2008, s. 345-346; Ż. Gwardzińska, Egzekucja nadzoru konserwatorskiego, Wydawnictwo Uniwersytetu Gdańskiego, Gdańsk 2019, s. 160; T. Jędrzejewski, M. Masternak, P. Rączka, Administracyjne postępowanie egzekucyjne, TNOiK, Toruń 2020, s. 227 i n.

7 W. Piątek, A. Skoczylas, op. cit., nb 337; Ż. Gwardzińska, op. cit., s. 59 i 72.

8 Ustawa z dnia 23 lipca 2003 r. o ochronie zabytków i opiece nad zabytkami, tekst. jedn. Dz. U. z 2018 r., poz. 2067 ze zm. Ustawa ta obowiązuje w miejsce uchylonej ustawy o ochronie dóbr kultury z dnia 15 lutego 1962 r., tekst jedn. Dz. U. z 1999 r. Nr 98, poz. 1150 ze zm.

9 Zob. przede wszystkim art. 5 i art. 55 u.o.z. Szerzej: A. Stelmachowski, w: Z. Radwański (red.), System Prawa Prywatnego, t. 3: T. Dybowski (red.), Prawo rzeczowe, C.H. Beck, Warszawa 2007, s. 208-212. 
szczególny reżim prawny wobec tego rodzaju przedmiotów występuje w przepisach regulujących egzekucję?

W unormowaniach dotyczących egzekucji sądowej, tj. w Kodeksie postępowania cywilnego, pojęcie zabytku w ogóle się nie pojawia. Za to w sposób szczególny w ramach egzekucji z ruchomości unormowano egzekucję skierowaną do rzeczy „o wartości historycznej lub artystycznej”. Z kolei co do egzekucji administracyjnej $z$ ruchomości istniały do tej pory przepisy regulujące egzekucję skierowaną do ruchomości stanowiącej zabytek (przedmiotu stanowiącego zabytek), lecz regulacja ta zmieniła się na mocy nowelizacji, która weszła w życie w dniu 30 lipca 2020 r. $^{10}$ Od tej pory w przepisach ustawy jest mowa już nie o zabytku, lecz o „ruchomości o wartości historycznej, artystycznej lub naukowej"11.

Z tego, co powiedziano, wynika, że regulacje zamieszczone w Kodeksie postępowania cywilnego i w ustawie o postępowaniu egzekucyjnym $w$ administracji nie posługując się wprost pojęciem zabytku - nawiązują swoimi sformułowaniami do wyżej przytoczonej legalnej definicji zabytku' ${ }^{12}$.

$W$ art. $866^{2} \S 1$ k.p.c., w którym jest mowa o „przedmiotach o wartości historycznej lub artystycznej", znajdują się uregulowania szczególne odnoszące się do oszacowania i sprzedaży takiego przedmiotu ${ }^{13}$. Wcześniej te kwestie regulował art. 865 § 2 k.p.c., który dotyczył sprzedaży egzekucyjnej „przedmiotów o wartości historycznej, naukowej lub artystycznej". Użycie przez ustawodawcę takiego sformułowania prowadziło do objęcia ochroną w postępowaniu egzekucyjnym ${ }^{14}$ nie tylko przedmiotów, które były wpisane do rejestru zabytków; na gruncie wy-

10 Ustawa z dnia 11 września 2019 r. o zmianie ustawy o postępowaniu egzekucyjnym w administracji oraz niektórych innych ustaw, Dz. U. poz. 2070.

11 Zob. art. 100 § 3 i 105 § 2 u.p.e.a., o których jest mowa w dalszej części opracowania. Kryteria w postaci tych trzech wartości - pozwalające wyodrębnić przedmioty materialne zasługujące na zachowanie w możliwie nienaruszonym stanie - są tożsame w większości ustawodawstw europejskich, a pojawiły się już w XIX w.; J. Pruszyński, Stan i potrzeby regulacji prawnej ochrony zabytków w Polsce, „Ochrona Zabytków" 1996, nr 3, s. 292. Warto zwrócić uwagę, że na gruncie przepisów Kodeksu cywilnego ustawodawca postąpił odwrotnie, a mianowicie występujące w art. 187 i 189 k.c. pojęcia „rzeczy mających wartość naukową lub artystyczną" zastąpiono - na mocy ustawy z dnia 20 lutego 2015 r. o rzeczach znalezionych (Dz.U. poz. 397) - pojęciem rzeczy „będącej zabytkiem lub materiałem archiwalnym”. Zdecydowaną krytykę poprzedniego stanu prawnego przeprowadził K. Mularski, O skarbach de lege lata i de lege ferenda, „Monitor Prawniczy" 2009, nr 12, s. 643-654.

12 Por. uzasadnienie projektu ustawy z dnia 11 września 2019 r. o zmianie ustawy o postępowaniu egzekucyjnym w administracji oraz niektórych innych ustaw, Druk sejmowy Sejmu VIII kadencji nr 3753, s. 100, http://www.sejm.gov.pl; dalej powoływane jako Uzasadnienie projektu.

13 Przepis art. 866 został wprowadzony do Kodeksu postępowania cywilnego ustawą z dnia 2 lipca 2004 r. o zmianie ustawy Kodeks postępowania cywilnego oraz niektórych innych ustaw, Dz. U. Nr 172, poz. 1804.

14 Oferty w ramach sprzedaży egzekucyjnej tego rodzaju przedmiotów komornikowi - według pierwotnej treści tego przepisu - wolno było skierować tylko do kręgu podmiotów wymienionych w tym przepisie, tj. państwowego muzeum, biblioteki, archiwum albo przedsiębiorstwa państwowego zajmującego się obrotem takimi przedmiotami. Pierwotna treść przepisu wynikała z ówczesnych ideologicznych założeń ustrojowych. 
Administracyjna i sądowa egzekucja z ruchomości o wartości historycznej... Administrative and judicial execution against movables possessing historical...

żej wspomnianej ustawy o ochronie dóbr kultury ${ }^{15}$ istniały bowiem zabytki jako przedmioty zarejestrowane i pozostałe dobra kultury. W stosunku do pierwotnego brzmienia kodeksu (konkretnie art. $865 \S 2$ będącego odpowiednikiem obecnego art. $866^{2}$ k.p.c.) regulacja obecnie obowiązująca nie obejmuje przedmiotów o wartości naukowej ${ }^{16}$, a wobec tego egzekucja z takich rzeczy toczy się na zasadach ogólnych ${ }^{17}$.

Z kolei ustawa o postępowaniu egzekucyjnym $w$ administracji $w$ brzmieniu pierwotnym częściowo w sposób szczególny regulowała egzekucję skierowaną do „przedmiotu o wartości zabytkowej” - wart. 96 § 3 (później tak w art. 100 § 3) i równolegle - w art. $101 \S 2$, gdzie zastosowano terminologię „przedmioty o wartości historycznej, naukowej lub artystycznej" (później tak samo w art. 105 § 2). Od 30 listopada 2001 r. w art. 100 § 3 i w art. 105 § 2 u.p.e.a. była mowa odpowiednio o "ruchomości stanowiącej dobro kultury” i o „przedmiotach stanowiących dobro kultury"18. Na mocy ustawy z dnia 18 marca 2010 r. o zmianie ustawy o ochronie zabytków i opiece nad zabytkami oraz o zmianie niektórych innych ustaw ${ }^{19}$ przepisy art. $100 \S 3 \mathrm{i}$ art. $105 \S 2$ u.p.e.a. zmieniono ${ }^{20}$. Zmianą tą wprowadzono do ustawy o postępowaniu egzekucyjnym $w$ administracji jeszcze inną terminologię: „ruchomość stanowiąca zabytek $w$ rozumieniu ustawy o ochronie zabytków i opiece nad zabytkami” i „przedmioty stanowiące zabytek”. Z dniem 30 lipca 2020 r. weszła w życie wyżej wspomniana nowelizacja ustawy, m.in. w zakresie przepisów regulujących egzekucję skierowaną do tej kategorii ruchomości, a konkretnie do ich szacowania, przechowywania i sprzedaży, przy tym - jak wyżej wskazano - usunięty został z ustawy termin „zabytek”.

Wobec tego zasadne staje się przeprowadzenie rozważań mających na celu zbadanie, na czym polegają zmiany w stanie prawnym oraz jaki jest cel tych zmian ustawodawczych. Zachodzi też potrzeba porównania treści tych uregulowań z treścią stosownych przepisów regulujących egzekucję sądową, tym bardziej że w kwestii sprzedaży ruchomości przepisy Kodeksu postępowania cywilnego zostały w ostatnich latach istotnie znowelizowane (wprowadzono licytację elektroniczną ${ }^{21}$ ). Przy dokonywaniu tych porównań należy oczywiście mieć na uwa-

\footnotetext{
15 Zob. przypis 8.

16 S. Cieślak, komentarz do art. 866² , w: J. Jankowski (red.), Kodeks postępowania cywilnego, t. 2: Komentarz, art. 730-1217, Warszawa 2019, Legalis.

17 Z. Merchel, op. cit., s. 153; idem, w: Egzekucja sadowa w Polsce, pod kier. Z. Szczurka, Currenda, Sopot 2007 , s. 360 .

18 Na mocy ustawy z dnia 6 września 2001 r. o zmianie ustawy o postępowaniu egzekucyjnym w administracji oraz niektórych innych ustaw, Dz. U. Nr 125, poz. 1368.

19 Ustawa z dnia 18 marca 2010 r. o zmianie ustawy o ochronie zabytków i opiece nad zabytkami oraz o zmianie niektórych innych ustaw, Dz. U. Nr 75, poz.474.

20 Dotyczy to również art. $105 \S 2$ w zw. z art. $99 \S 3$ u.p.e.a.

21 Ustawa z dnia 10 lipca 2015 r. o zmianie ustawy - Kodeks cywilny, ustawy - Kodeks postępowania cywilnego oraz niektórych innych ustaw (Dz. U. poz. 1311) z mocą od dnia 8 września 2016 r.
} 


\section{ARTYKUtY}

Marek Mrówczyński

dze odmienności systemu podmiotów sądowego postępowania egzekucyjnego i administracyjnego postępowania egzekucyjnego, wyrażające się w częściowo różnej terminologii. Egzekucję sądową z ruchomości prowadzi komornik sądowy; wyróżnia się strony sądowego postępowania egzekucyjnego, którymi są wierzyciel i dłużnik. W egzekucji administracyjnej mamy do czynienia z następującymi podmiotami obligatoryjnymi: organ egzekucyjny (jako organ prowadzący postępowanie egzekucyjne), wierzyciel i zobowiązany, przy czym w niektórych wypadkach wierzyciel jest jednocześnie organem egzekucyjnym ${ }^{22}$. Inną kwestią, którą trzeba mieć na uwadze, jest okoliczność, że egzekucja wszczęta w postępowaniu administracyjnym może - na skutek zbiegu z egzekucją sądową - być następnie prowadzona przez komornika sądowego, i to według przepisów o egzekucji sądowej, a także odwrotnie: możliwe jest, że wszczęta przez komornika egzekucja sądowa dalej będzie prowadzona przez organ egzekucyjny według przepisów o egzekucji administracyjnej (zob. art. 773 k.p.c. i art. 62, art. 62d § 1, art. 62e § 1 u.p.e.a.).

Ruchomość o wartości historycznej, naukowej lub artystycznej może w niektórych wypadkach w ogóle nie podlegać egzekucji. Ten problem nie może więc być pominięty w tych rozważaniach. Najpierw jednak należy rozważyć samo pojęcie rzeczy o wartości historycznej, naukowej lub artystycznej.

\section{Pojęcie rzeczy o wartości historycznej, naukowej lub artystycznej}

To, czy dany przedmiot posiada wartość historyczną, naukową lub artystyczną, nierzadko nie podlega jednoznacznej ocenie ${ }^{23}$. Określenie wartości historycznej może zależeć od tego, czy i jakie dostępne są informacje o pochodzeniu przedmio$\mathrm{tu}^{24}$. Natomiast wartość artystyczna to tradycyjne kryterium wyróżnienia dzieł sztuki, w nauce prawa z góry uznawane za przesłankę budzącą ze swej istoty liczne wątpliwości ${ }^{25}$. Przede wszystkim z jednej strony pojęcie tej wartości nacechowane jest subiektywnie (zależy od wrażliwości czy wykształcenia osoby oceniającej), z drugiej strony wpływają na tę wartość elementy obiektywne, takie jak rynek, nurty w sztuce ${ }^{26}$. Przy tym nie ma niezmiennego wzorca wartości artystycznych;

\footnotetext{
22 Zob. W. Piątek, A. Skoczylas, op. cit., nb 127; L. Klat-Wertelecka, Niedopuszczalność egzekucji administracyjnej, Wydawnictwo Uniwersytetu Wrocławskiego, Wrocław 2009, s. 284-285; Ż. Gwardzińska, op. cit. s. 62.

23 Zob. M. Zajęcki, Definiowanie pojęć podstawowych prawa kultury w kontekście zasad wykładni prawa polskiego, w: A. Jagielska-Burduk, W. Szafrański (red.), Kultura w praktyce. Zagadnienia prawne, Wydawnictwo Poznańskiego Towarzystwa Przyjaciół Nauk, Poznań 2012, s. 29. K. Mularski (op. cit., s. 653) uznaje zwłaszcza sformułowania „wartość naukowa i „wartość artystyczna” za zwroty niedookreślone.

24 A. Jagielska-Burduk, Zabytek ruchomy, Wolters Kluwer Polska, Warszawa 2011, s. 72.

25 Zob. J. Pruszyński, op. cit., s. 292; K. Mularski, op. cit., s. 645; J. Kozińska, P. Stec, Odpowiedzialność za wady dzieła sztuki po nowelizacji Kodeksu cywilnego, „Santander Art and Culture Law Review” 2015, nr 1, s. 180.

26 Zob. A. Jagielska-Burduk, op. cit., s. 48 i 93.
} 
Administracyjna i sądowa egzekucja z ruchomości o wartości historycznej... Administrative and judicial execution against movables possessing historical...

w różnych epokach mogą istnieć różne powszechnie uznawane kanony estetyczne ${ }^{27}$. Z kolei kryterium wartości naukowej oznacza tyle, że przedmiot powinien mieć znaczenie dla ludzkiego poznania ${ }^{28}$. Przy założeniu ścisłego rozumienia tego kryterium wydaje się, że taka wartość jakiegoś przedmiotu istniejąca samodzielnie - tj. bez jednoczesnego występowania wartości historycznej lub artystycznej stanowi wypadek stosunkowo rzadki w praktyce ${ }^{29}$.

Wartości historyczna, naukowa lub artystyczna mogą występować łącznie lub pojedynczo; z tym że dla zaliczenia przedmiotu do kategorii zabytków konieczne jest, by występowały w takim natężeniu, aby zachowanie przedmiotu było istotne z punktu widzenia społecznego ${ }^{30}$. Ustawowa kwalifikacja zabytku jest - jak widać dwustopniowa ${ }^{31}$.

O tym, czy dany obiekt posiada wymienione wartości, najczęściej pozwala przesądzić postępowanie prowadzące do wydania decyzji o wpisie do rejestru zabytków ${ }^{32}$. W myśl art. 7 pkt 1 u.o.z. wpis do rejestru zabytków jest formą ochrony zabytku. Rejestr prowadzi wojewódzki konserwator zabytków. Z art. 10 u.o.z. wynika, że wpis następuje $w$ drodze decyzji wydawanej na wniosek właściciela zabytku, a wyjątkowo z urzędu. Stosownie do art. 11 u.o.z. do rejestru nie wpisuje się jednak zabytku wpisanego do inwentarza muzeum lub wchodzącego w skład narodowego zasobu bibliotecznego ${ }^{33}$. Na gruncie obecnej ustawy o ochronie zabytków i opiece nad zabytkami, jak widać, występuje dualizm: możemy mieć do czynienia z zabytkiem lub zabytkiem ujętym $w$ rejestrze ${ }^{34}$. Od rejestru zabytków należy od-

27 A. Jagielska-Burduk, op. cit., s. 31-32. Co do relacji pojęć wartości artystycznej i wartości estetycznej zob. M. Zajęcki, op. cit., s. 35-36; K. Zeidler, Wartości zabytku jako kategoria normatywna, w: idem, Zabytki. Prawo i praktyka, Wydawnictwo Uniwersytetu Gdańskiego, Wolters Kluwer, Gdańsk-Warszawa 2017, s. 123-130. Zob. też idem, Prawo ochrony dziedzictwa kultury, Wolters Kluwer Polska, Warszawa 2007, s. 62-64.

28 Zob. K. Mularski, op. cit., s. 644.

29 Przykładem przedmiotu mającego taką wartość mogłoby być jakieś prototypowe urządzenie czy maszyna. Inny możliwy przykład to jakieś znalezisko przyrodnicze, lecz trudne do wyobrażenia jest, by w praktyce do takiego przedmiotu została skierowana egzekucja.

30 A. Jagielska-Burduk, op. cit., s. 71. Zob. też Ł. Gaweł, Dziedzictwo kulturowe - ustalenia podstawowe, w: A. Jagielska-Burduk (red.) Mechanizmy prawne zarządzania dziedzictwem kultury, Wydawnictwo Uniwersytetu Gdańskiego, Wolters Kluwer, Gdańsk-Warszawa 2017, s. 21-22.

31 Zob. K. Mularski, op. cit., s. 649.

32 A. Jagielska-Burduk, op. cit., s. 71.

33 Narodowy zasób biblioteczny stanowią zbiory bibliotek mające wyjątkową wartość i znaczenie dla dziedzictwa narodowego. Określenie kryteriów zaliczania zbiorów do narodowego zasobu bibliotecznego, a także wykazu bibliotek posiadających zbiory zaliczane do tego zasobu, należy do ministra właściwego do spraw kultury i ochrony dziedzictwa narodowego (zob. art. 6 ustawy z dnia 27 czerwca 1997 r. o bibliotekach, tekst jedn. Dz. U. z 2019 r., poz. 1479).

34 Odpowiada to wcześniejszym pojęciom „dobro kultury” i „zabytek”; zob. A. Jagielska-Burduk, op. cit., s. 83. Status zabytku obiekty posiadają niezależnie od stanu zachowania (tak wprost art. 6 ust. 1 u.o.z.). Jednak art. 13 u.o.z. reguluje też utratę statusu zabytku. I tak: zabytek wpisany do rejestru, który uległ zniszczeniu w stopniu powodującym utratę jego wartości historycznej, artystycznej lub naukowej albo którego wartość będąca podstawą wydania decyzji o wpisie do rejestru nie została potwierdzona w no- 


\section{ARTYKUtY}

Marek Mrówczyński

różnić ewidencję zabytków (krajową, wojewódzką, gminną). Na gruncie przepisów ustawy o ochronie zabytków i opiece nad zabytkami możliwa jest sytuacja, w której ruchomość zabytkowa figuruje w wojewódzkiej ewidencji zabytków, choć nie jest wpisana do rejestru zabytków ${ }^{35}$.

Dokonane przez ustawodawcę przykładowe wyliczenie przedmiotów pozwala na rozstrzygnięcie wątpliwości interpretacyjnych co do zakresu pojęcia zabytku³6. Otóż - jak wynika z uregulowań ustawy o ochronie zabytków i opiece nad zabytka$\mathrm{mi}^{37}$ - zabytkami ruchomymi mogą być w szczególności: dzieła sztuk plastycznych, rzemiosła artystycznego i sztuki użytkowej, kolekcje stanowiące zbiory przedmiotów zgromadzonych i uporządkowanych według koncepcji osób, które stworzyły te kolekcje, numizmaty i pamiątki historyczne (zwłaszcza militaria, sztandary, pieczęcie, odznaki, medale, ordery), wytwory techniki, takie jak urządzenia, środki transportu, maszyny i narzędzia; materiały biblioteczne, o których mowa w art. 5 ustawy z 27 czerwca 1997 r. o bibliotekach, instrumenty muzyczne, wytwory sztuki ludowej i rękodzieła, przedmioty upamiętniające wydarzenia historyczne bądź działalność wybitnych osobistości lub instytucji.

Zabytkiem w myśl ustawy o ochronie zabytków i opiece nad zabytkami może być część rzeczy. Na gruncie postępowania egzekucyjnego jednak i tak zawsze zajęciu podlega rzecz jako całość, a nie jej poszczególne części. Część składowa rzeczy nie może być osobnym przedmiotem egzekucjï.

Stosownie do tego, co powiedziano, każdy zabytek implicite posiada - w myśl definicji ustawowej - wartość historyczną, artystyczną lub naukową, natomiast z drugiej strony istnieją przedmioty, które posiadają wartość historyczną, artystyczną lub naukową, lecz nie w takim natężeniu, by stanowić zabytki.

Wynika z tego, że pojęcie ruchomości o wartości historycznej, naukowej lub artystycznej, występujące na gruncie regulacji egzekucji administracyjnej z ruchomości, ma szerszy zakres znaczeniowy niż normatywne pojęcie zabytku. Podobnie jest z pojęciem przedmiotu o wartości historycznej lub artystycznej, którym ustawodawca posłużył się na gruncie regulacji sądowej egzekucji z ruchomości, z tym że w tym wypadku występuje też pewne zawężenie znaczeniowe w stosunku do pojęcia zabytku, gdyż wyłączony jest element wartości naukowej. Stąd płynie jednocześnie wniosek, że utożsamianie w niektórych wypowiedziach

wych ustaleniach naukowych, zostaje skreślony z rejestru (dalsze wypadki skreślenia są następujące: gdy zabytek został wpisany na Listę Skarbów Dziedzictwa, został wpisany do inwentarza muzeum lub wszedł w skład narodowego zasobu bibliotecznego). Skreślenie następuje decyzją ministra właściwego do spraw kultury i ochrony dziedzictwa narodowego.

35 Zob. art. 22 u.o.z. Szerzej o ewidencji P. Antoniak, w: M. Cherka (red.), Ustawa o ochronie zabytków i opiece nad zabytkami, komentarz, Lex 2010.

36 M. Zajęcki, op. cit., s. 35 .

37 Zob. art. 6 ust. 1 pkt 2 u.o.z.

38 Z. Merchel, Ruchomość jako przedmiot..., s. 15. 
Administracyjna i sądowa egzekucja z ruchomości o wartości historycznej... Administrative and judicial execution against movables possessing historical...

doktrynalnych pojęcia ruchomości o wartości historycznej z pojęciem ruchomości zabytkowych jest bezpodstawne ${ }^{39}$.

\section{Wypadki, w których ruchomość o wartości historycznej, naukowej lub artystycznej nie podlega egzekucji}

Rzecz może nie podlegać egzekucji właśnie ze względu na swoją wartość historyczną, naukową lub artystyczną. Otóż muzealia - jako rzeczy stanowiące dobro narodowe (zob. art. 21 ust. 1 zd. drugie ustawy z dnia 21 listopada 1996 r. o muze$a h^{40}$ ) - jeśli figurują w inwentarzu muzeum państwowego lub samorządowego, nie mogą być przedmiotem egzekucji sądowej ani egzekucji administracyjnej. Za muzealia uznaje się rzeczy (ruchome i nieruchome), które stanowią własność muzeum i przy tym zostały wpisane do inwentarza muzealiów, z tym zastrzeżeniem, że w wypadku muzeum nieposiadającego osobowości prawnej rzeczy te muszą stanowić własność podmiotu, który utworzył muzeum (zob. art. 21 ust. 1 i 1a ustawy o muzeach). Jak widać, o statusie prawnym muzealiów, a w konsekwencji - o niedopuszczalności kierowania do nich egzekucji decyduje przesłanka mająca charakter formalny. Nie ma też podstaw, by utożsamiać pojęcie muzealiów z ustawowym pojęciem zabytków ${ }^{41}$.

Dalsze wypadki niedopuszczalności kierowania egzekucji do rzeczy o wartości historycznej, naukowej lub artystycznej to te, w których rzecz o takiej wartości nie podlega egzekucji na zasadach ogólnych, tj. stosownie do ogólnych przepisów o ograniczeniach egzekucji. Z punktu widzenia rozważanej problematyki znaczenie mają tzw. przedmiotowe ograniczenia egzekucji ${ }^{42}$.

39 Takie utożsamienie nastąpiło w wypowiedzi Z. Merchla, Ruchomość jako przedmiot..., s. 153 (który mówi o ruchomości mającej charakter zabytkowy; zob. też przypis 56) oraz J. Lipińskiej, Biegły w postępowaniu egzekucyjnym (część druga). Zagadnienia szczegółowe, „Przegląd Prawa Egzekucyjnego” 2018, nr 1, s. 94, tam, gdzie jest mowa o "ruchomościach zabytkowych lub mających wartość artystyczną".

40 Ustawa z dnia 21 listopada 1996 r. o muzeach, tekst jedn. Dz. U. z 2019 r., poz. 917 ze zm.

41 Zob. art. 29a ust. 1 i 2 ustawy o muzeach, w których to przepisach jest mowa o "muzealiach, które nie stanowią zabytków". Generalnie natomiast to, w jakiej relacji pojęcie muzealiów pozostaje do pojęcia zabytku, jest sporne w doktrynie (zob. M. Zajęcki, op. cit., s. 31; K. Zeidler, Prawo ochrony..., s. 59-61; K. Zalasińska, Muzealia, zbiory, eksponaty, kolekcja muzealna oraz zasoby muzeum - pojęcia podstawowe w muzealnictwie, w: P. Stec, P.P. Maniurka (red.), Kolekcje i zbiory muzealne. Problematyka prawna, Wydawnictwo i Drukarnia Świętego Krzyża, Opole 2015, s. 8-11).

42 Należy je odróżnić od tzw. ograniczeń podmiotowych, czyli sytuacji niedopuszczalności egzekucji ze względu na podmiot. Jest to, po pierwsze, wypadek immunitetu egzekucyjnego (zob. art. 1115 § 1 k.p.c. oraz art. $1111 \S 1$ i art. 1112 § 1 k.p.c., art. 14 § 1 i 2 u.p.e.a.), przy tym w wyjątkowych wypadkach dopuszczalności egzekucji występują szczególne ograniczenia przedmiotowe, o których mowa wart. 1115 § 3 i 4 k.p.c. i art. 14 § 3 u.p.e.a. Po drugie, chodzi o egzekucję przeciwko Skarbowi Państwa i przeciwko Narodowemu Bankowi Polskiemu. Zgodnie z art. 1060 k.p.c. i art. 1060 k.p.c. w zw. z art. 57 ust. 2 ustawy z dnia 29 sierpnia 1997 r. o Narodowym Banku Polskim (tekst jedn. Dz. U. z 2019 r., poz. 1810), egzekucja przeciwko tym dwóm podmiotom może być ewentualnie prowadzona, lecz tylko z rachunku bankowego. Należy mieć na uwadze okoliczność, iż może się zdarzyć, że dana rzecz stanowi własność Skarbu Państwa dlatego, 


\section{ARTYKUtY}

Marek Mrówczyński

W przepisach o egzekucji administracyjnej dotyczy tego art. 8 \& 1 u.p.e.a. ${ }^{43}$ Otóż jeżeli chodzi o rzeczy, to nie podlegają egzekucji następujące spośród nich:

1) przedmioty urządzenia domowego niezbędne dla zobowiązanego i będących na jego utrzymaniu członków rodziny,

2) narzędzia i inne przedmioty niezbędne do pracy zarobkowej wykonywanej osobiście przez zobowiązanego (z wyłączeniem środka transportu),

3) przedmioty niezbędne do pełnienia służby przez zobowiązanego lub do wykonywania przez niego zawodu,

4) dokumenty osobiste, po jednej obrączce zobowiązanego i jego współmałżonka, wykonanej z metali szlachetnych, ordery i odznaczenia oraz przedmioty niezbędne zobowiązanemu i członkom jego rodziny do nauki lub wykonywania praktyk religijnych,

5) przedmioty codziennego użytku, które mogą być sprzedane znacznie poniżej ich wartości, a które dla zobowiązanego mają znaczną wartość użytkową,

6) rzeczy służące w kościołach i innych domach modlitwy do odprawiania nabożeństw lub do wykonywania innych praktyk religijnych albo będące obiektami kultu religijnego, choćby były kosztownościami lub dziełami sztuki.

Rozwinięcie regulacji w kwestii przedmiotów urządzenia domowego niezbędnych dla zobowiązanego i będących na jego utrzymaniu członków rodziny znajduje się w paragrafie 2 tego artykułu. Otóż w przepisie postanowiono, że nie uważa się za takie przedmioty m.in.: mebli stylowych i stylizowanych, futer ze skór szlachetnych, dywanów wełnianych i ze skór naturalnych, porcelany, szkła ozdobnego i kryształów, sztućców z metali szlachetnych, dzieł sztuki.

Odpowiednikiem wymienionych regulacji na gruncie sądowego postępowania egzekucyjnego jest art. 829 pkt 1, 4 i 6 k.p.c. Unormowania te są mniej rozbudowane; w przepisach nie wymieniono wprost obrączek ani wyposażenia kościołów i innych domów modlitwy. Niemniej w drodze wykładni przyjąć trzeba, że sformułowanie „przedmioty służące do wykonywania praktyk religijnych” odnosi się również do sprzętów liturgicznych, szat liturgicznych i urządzenia kościoła ${ }^{44}$. Nie można natomiast uznać, by ograniczeniem egzekucji objęte były takie przedmioty służące do wykonywania praktyk religijnych, które dłużnik wyrabia, którymi handluje lub które kolekcjonuje ${ }^{45}$.

że została przejęta na rzecz Skarbu Państwa w drodze decyzji wojewódzkiego konserwatora zabytków lub ministra właściwego do spraw kultury i ochrony dziedzictwa narodowego (dopuszczalność wydania takiej decyzji reguluje art. 50 ust. 4 pkt 1 i 1 a u.o.z.).

43 Szerzej: L. Klat-Wertelecka, op. cit., s. 315-318; P. Możyłowski, Zasady ogólne administracyjnego postępowania egzekucyjnego, „Studia Prawnicze KUL” 2016, nr 1, s. 115-118.

44 Por. uchwałę Sądu Najwyższego z dnia 17 września 1969 r., sygn. akt III CZP 68/69, dotyczącą wyjawienia majątku, OSNC 1970, z. 2, poz. 29.

45 Z. Merchel, Ruchomość jako przedmiot..., s. 51. 


\section{Zajęcie ruchomości o wartości historycznej, naukowej lub artystycznej oraz dozór nad tą ruchomością}

W egzekucji sądowej zajęcie ruchomości o wartości historycznej lub artystycznej następuje na podstawie ogólnych przepisów normujących egzekucję z ruchomości. W szczególności art. 845 § 2, § $2^{2}$ i § $2^{4}$ k.p.c. regulują dopuszczalność zajęcia ze względu na to, w czyim władaniu znajduje się rzecz. Z art. 847 § 1 zd. pierwsze k.p.c. wynika, że zajęcie ruchomości polega na jej wpisaniu do protokołu zajęcia. Na zajęcie przysługuje skarga na czynności komornika. Zgodnie z art. 855 § 1 zd. pierwsze k.p.c., zasadą jest, że zajęte ruchomości komornik pozostawia pod dozorem osoby, u której je zajął. Jednak w myśl art. 855 § 2 k.p.c. ze względu na właściwości rzeczy może ona być oddana na przechowanie właściwej instytucji. Dotyczy to m.in. właśnie ruchomości o wartości historycznej lub artystycznej ${ }^{46}$.

W egzekucji administracyjnej w kwestii zajęcia rzeczy o wartości historycznej naukowej lub artystycznej również stosuje się przepisy ogólne. Otóż dopuszczalność zajęcia ze względu na to, w czyim władaniu znajduje się rzecz, reguluje art. 97 § 2 i 3 u.p.e.a. Zgodnie z art. 98 § 1 zd. pierwsze u.p.e.a., zajęcie ruchomości następuje przez wpisanie jej do protokołu zajęcia i podpisanie protokołu przez pracownika obsługującego organ egzekucyjny. Zajęcie może być przez zobowiązanego zaskarżone skargą na czynność organu egzekucyjnego, uregulowaną w art. 54 u.p.e.a.

Zauważyć należy, że już przy samym zajęciu mogą pojawić się problemy praktyczne istotne z punktu widzenia rozważanej tu problematyki. W szczególności wydaje się konieczne uwzględnienie przepisów ustawy o ochronie zabytków i opiece nad zabytkami regulujących kwestie kolekcji ${ }^{47}$.

\footnotetext{
46 Na podstawie art. 855 § 3 k.p.c. zostało wydane rozporządzenie Ministra Sprawiedliwości z dnia 16 sierpnia 2016 r. w sprawie oddawania zajętych ruchomości do depozytu sądowego albo na przechowanie właściwym instytucjom (Dz. U. poz. 1326), którego § 2 ust. 1 brzmi: państwowa lub samorządowa instytucja kultury, a w szczególności muzeum, archiwum lub biblioteka, jest instytucją właściwą do przechowywania ruchomości stanowiącej zabytek. Zgodnie z ust. 2, do wskazania tej instytucji właściwy jest wojewódzki konserwator zabytków, a w przypadku materiałów bibliotecznych - dyrektor Biblioteki Narodowej w Warszawie.

47 Istnieje problem, czy dopuszczalne jest skierowanie egzekucji do jednego tylko z przedmiotów o charakterze zabytkowym tworzących kolekcję. Kolekcję - na gruncie obecnie obowiązującej ustawy o ochronie zabytków i opiece nad zabytkami - trzeba traktować jako jeden zabytek, na który składa się pewna liczba elementów (zob. A. Jagielska-Burduk, op. cit., s. 77). Rozporządzenie jednym z elementów kolekcji rozrywa kolekcję, a tym samym narusza substancję zabytku (szerzej: ibidem, s. 152-153). Tak samo w wypadku zajęcia i sprzedaży egzekucyjnej takiego pojedynczego przedmiotu. Tymczasem jeśli zabytek wpisany jest do rejestru zabytku, podejmowanie działań naruszających jego substancję wymaga - jak stanowi art. 36 ust. 1 pkt 11 u.o.z. - uzyskania pozwolenia wojewódzkiego konserwatora zabytków. W kwestii charakteru prawnego kolekcji zob. ponadto P. Stec, Kolekcja jako przedmiot obrotu cywilnoprawnego, w: P. Stec, P.P. Maniurka (red.), Kolekcje i zbiory..., s. 79-95; K. Zalasińska, op. cit., s. 18-19.
} 


\section{ARTYKUtY}

\section{Marek Mrówczyński}

Zajęcie wiąże się z koniecznością oszacowania zajętych ruchomości ${ }^{48}$. Ustawodawca przyjął założenie, że wycena ruchomości, których dotyczą niniejsze rozważania, wymaga wiedzy specjalistycznej.

Przepis art. $866^{2} \S 1$ zd. pierwsze k.p.c. stanowi, że do oszacowania zajętych przedmiotów o wartości historycznej lub artystycznej komornik wzywa biegłego. Przepis ten to lex specialis w stosunku do art. 853 § 2 k.p.c., z którego wynika, że zasadą jest, iż komornik przy zajęciu sam szacuje wartość ruchomości i oznacza ją w protokole zajęcia ${ }^{49}$. Przedmiot o wartości historycznej lub artystycznej może być wykonany ze złota lub platyny. W takiej sytuacji zastosowanie ma art. $866^{2} \S 2$ zd. pierwsze k.p.c., który zawiera analogiczną regulację jak § 1: do oszacowania wyrobów ze złota i platyny komornik powołuje biegłego. Na gruncie egzekucji administracyjnej kwestii tych dotyczy art. 99 § 3 u.p.e.a., z którego wynika, że jeżeli zajęte ruchomości są ruchomościami o wartości historycznej, naukowej lub artystycznej, to oszacowania dokonuje biegły skarbowy ${ }^{50} i$ to samo odnosi się do kosztowności. Szacowanie natomiast wszelkich innych zajętych ruchomości przez biegłego skarbowego jest fakultatywne. Niewątpliwie ruchomość o wartości historycznej, naukowej lub artystycznej może jednocześnie należeć do kategorii kosztowności. Pojęcie kosztowności jest szerokie i obejmuje nie tylko przedmioty wykonane ze złota, srebra i platyny, ale też wyroby np. z koralu, bursztynu, perły czy kamienia szlachetnego ${ }^{51}$. Kosztowność natomiast - zgodnie $z$ art. 99 § 3a u.p.e.a. - nie może być oszacowana poniżej wartości kruszcu lub materiału, z którego została wytworzona. Inną kwestią, która wpływa na oszacowanie - zarówno w egzekucji administracyjnej, jak i sądowej - jest to, czy i jaką wartość użytkową jednocześnie ma ruchomość o wskazanych wyżej cechach.

Pojawia się pytanie, skąd pracownik obsługujący organ egzekucyjny ma wiedzieć, że zajęta w egzekucji administracyjnej rzecz ma wartość historyczną, naukową lub artystyczną, a w wypadku egzekucji sądowej - skąd komornik ma wiedzieć, że rzecz ma wartość historyczną lub artystyczną. Przede wszystkim w niektórych wypadkach możliwe jest przyjęcie założenia o istnieniu już z samej istoty wartości artystycznej, co odnosi się do takich rzeczy, jak obraz czy rzeźba. Poza tym sam dłużnik przy zajęciu może oświadczyć, że dany przedmiot ma wartość historyczną, naukową lub artystyczną, a nawet przedstawić dokumenty poświadczające tę okoliczność. W każdym razie - czy to na podstawie twierdzeń dłużnika, czy nawet bez

48 Nawiązując do problematyki kolekcji, należy zauważyć, że oszacowanie dotyczy zawsze każdej rzeczy indywidualnie, szacowaniu nie podlega zbiór rzeczy; zob. uchwałę Sądu Najwyższego z dnia 9 grudnia 1986 r., sygn. akt III CZP 61/86, OSNCP 1987, z. 9, poz. 129.

49 S. Cieślak, komentarz do art. 866², w: J. Jankowski (red.), op. cit.

50 W dotychczasowym stanie prawnym obowiązek powierzenia oszacowania zajętego zabytku biegłemu skarbowemu wynikał z art. 105 § 2 zd. drugie w zw. $z$ art. 99 § 3 u.p.e.a. Zgodnie $z$ art. 1a pkt 1 tej ustawy, biegły skarbowy to rzeczoznawca w określonej dziedzinie, uprawniony do wyceny majątku zobowiązanego i wpisany na listę biegłych skarbowych prowadzoną przez izbę administracji skarbowej.

51 Zob. Uzasadnienie projektu, s. 99-100. 
Administracyjna i sądowa egzekucja z ruchomości o wartości historycznej... Administrative and judicial execution against movables possessing historical...

takich twierdzeń - może zaistnieć przypuszczenie, że rzecz ma wartość historyczną lub artystyczną, a w wypadku egzekucji administracyjnej - także wartość naukową.

W egzekucji administracyjnej pracownik obsługujący organ egzekucyjny może w razie takiego przypuszczenia wezwać zobowiązanego do wyjaśnienia, czy zajmowany przedmiot jest wpisany do rejestru zabytków ${ }^{52}$. Jeżeli okaże się, że tak, to kwestia wartości historycznej, naukowej lub artystycznej jest przesądzona. W pozostałych wypadkach organ egzekucyjny postąpi stosownie do art. 100 $\S 3$ u.p.e.a. Według dotychczasowego brzmienia art. $100 \S 3$ zd. pierwsze u.p.e.a., zajętą ruchomość stanowiącą zabytek poborca skarbowy oddawał pod dozór państwowej lub samorządowej instytucji kultury. Obecnie regulację rozbudowano. Otóż po nowelizacji art. 100 § 3 u.p.e.a. stanowi, że państwowa lub samorządowa instytucja kultury ${ }^{53}$ jest właściwa do sprawowania dozoru nad zajętą ruchomością o wartości historycznej, naukowej lub artystycznej, ale również takiej, co do której istnieje przypuszczenie, że ma wartość historyczną, naukową lub artystyczną ${ }^{54}$. Zgodnie $z$ art. 100 § 3a u.p.e.a., jednocześnie $z$ oddaniem pod dozór państwowej lub samorządowej instytucji kultury organ egzekucyjny występuje do wojewódzkiego konserwatora zabytków właściwego ze względu na miejsce przechowywania zajętej ruchomości, a w przypadku materiału bibliotecznego - do dyrektora Biblioteki Narodowej w Warszawie, z wnioskiem o wskazanie w wyznaczonym terminie:

- czy zajęta ruchomość, co do której istnieje przypuszczenie, że ma wartość historyczną, naukową lub artystyczną, rzeczywiście ma taką wartość,

- która państwowa lub samorządowa instytucja kultury jest właściwa do sprawowania dozoru i nabycia ruchomości.

Wydaje się, że skoro wprowadzono taką regulację, to - biorąc pod uwagę względy sprawności postępowania - zakłada się, że dokonaną ocenę co do tego, czy rzecz ma wartość historyczną, naukową lub artystyczną, organ egzekucyjny ma traktować jako wiążącą.

Co do samego oszacowania przez biegłego skarbowego, to zobowiązanemu doręcza się odpis protokołu tego oszacowania. W razie gdy zobowiązany nie zgadza się z tym oszacowaniem, może w terminie siedmiu dni od doręczenia mu odpisu protokołu wystąpić do organu egzekucyjnego z wnioskiem o dokonanie oszacowania przez biegłego sądowego (art. 67d § 2 u.p.e.a.).

\footnotetext{
52 Zob. R. Hauser, komentarz do art. 105, w: R. Hauser, A. Skoczylas (red.), Postępowanie egzekucyjne w administracji. Komentarz, Warszawa 2018, Legalis.

53 Instytucjami kultury są jednostki organizacyjne prowadzące działalność kulturalną tworzone przez centralne organy rządowe i jednostki samorządu terytorialnego. Ich tworzenie i działalność reguluje ustawa z dnia 25 października 1991 r. o organizowaniu i prowadzeniu działalności kulturalnej, tekst jedn. Dz. U. z 2020 r., poz. 194.

54 Por. sformułowanie zawarte w rozporządzeniu wydanym na podstawie art. 855 § 3 k.p.c., przytoczone wyżej w przypisie 46. Jednocześnie z takiego sformułowania przepisu pośrednio wynika, że w razie braku możliwości magazynowych czy technicznych wystarczające będzie, że instytucja ta wskaże podmiot, któremu rzecz będzie mogła być oddana pod dozór; zob. Uzasadnienie projektu, s. 101.
} 


\section{ARTYKUtY}

\section{Marek Mrówczyński}

W przepisach Kodeksu postępowania cywilnego o egzekucji sądowej rozważany problem nie jest tak ściśle uregulowany. Podstawą działań komornika w tym wypadku jest, po pierwsze, rozporządzenie wydane na podstawie art. 855 § 3 k.p.c. ${ }^{55}$, według którego wojewódzki konserwator zabytków, a w wypadku materiałów bibliotecznych - dyrektor Biblioteki Narodowej w Warszawie, jest właściwy do wydania opinii, czy ruchomość stanowi zabytek. Po drugie, podstawą tą są ogólne przepisy art. 761 § 1 (stwarzający komornikowi możliwość żądania informacji niezbędnych do prowadzenia egzekucji) i art. 813 k.p.c. ${ }^{56} \mathrm{Na}$ ich podstawie komornik może:

- zwrócić się do dłużnika o podanie, czy przedmiot jest wpisany do rejestru zabytków, a jeżeli tak, to u którego konserwatora,

- zwrócić się do muzeum lub innej instytucji kultury o informację, czy dany przedmiot ma wartość historyczną lub artystyczną,

- dopuścić dowód z opinii biegłego celem dokonania takiej oceny ${ }^{57}$.

Jeżeli ruchomość figuruje w rejestrze zabytków (lub w ewidencji zabytków), to konieczność stosowania przepisu art. $866^{2} \S 1$ zd. pierwsze k.p.c. jest przesądzona.

Biegły może być potrzebny również do ustalenia, czy zajęte przedmioty są wykonane ze złota lub platyny ${ }^{58}$. Sytuacja jest więc podobna jak w egzekucji administracyjnej, w której oceny biegłego skarbowego może wymagać to, czy zajęte przedmioty stanowią kosztowności.

W sądowym postępowaniu egzekucyjnym zastosowanie ma art. 278 § 3 k.p.c., w którym jest mowa o ustnej lub pisemnej formie opinii biegłego; w praktyce zasadą w postępowaniu egzekucyjnym jest jednak sporządzanie opinii na piśmie ${ }^{59}$.

Nie ma związania komornika opinią biegłego - ani w kwestii, czy przedmiot ma wartość historyczną lub artystyczną, ani w kwestii, czy jest wykonany ze złota lub platyny, ani co do oszacowania. Komornik może w razie wątpliwości wezwać biegłego do usunięcia uchybień; może również zlecić wydanie opinii innemu biegłemu, zwłaszcza jeżeli oszacowanie zostało zakwestionowane przez stronę ${ }^{60}$.

\footnotetext{
55 Zob. przypis 46.

56 Jednak Z. Merchel (Ruchomość jak przedmiot..., s. 153) twierdzi inaczej, a mianowicie, że dla dokonania oceny, „czy ruchomość ma charakter zabytkowy”, komornik obligatoryjnie powołuje biegłego.

57 Należy zwrócić uwagę, że w myśl art. 101 ust. 1 i 2 u.o.z. rzeczoznawca w określonej dziedzinie opieki nad zabytkami, któremu uprawnienia przyznał minister właściwy do spraw kultury i ochrony dziedzictwa narodowego, ma prawo do wydawania ocen i opinii, m.in. na rzecz organów wymiaru sprawiedliwości. Por. $\S 8$ rozporządzenia Ministra Kultury z dnia 10 maja 2004 r. w sprawie rzeczoznawców Ministra Kultury w zakresie opieki nad zabytkami (Dz. U. Nr 124, poz. 1302). Zob. jednocześnie art. 813 § 1 i 2 k.p.c.

58 A. Adamczuk, w: M. Manowska (red.), Kodeks postępowania cywilnego. Komentarz, t. 2: art. 506-1217, Lexis Nexis, Warszawa 2011, s. 580.

59 Por. J. Lipińska, Biegły w postępowaniu egzekucyjnym. Zagadnienia ogólne (część pierwsza), „Przegląd Prawa Egzekucyjnego" 2017, nr 10, s. 32.

60 Zob. Z. Merchel, w: Egzekucja sqdowa..., s. 340; I. Gil, komentarz do art. 853, w: E. Marszałkowska-Krześ (red.), Kodeks postępowania cywilnego. Komentarz, Warszawa 2019, Legalis. Co do skargi na czynności komornika w tej sytuacji zob. K. Flaga-Gieruszyńska, komentarz do art. 866², w: A. Zieliński, K. Flaga-Gieruszyńska (red.) Kodeks postępowania cywilnego. Komentarz, Warszawa 2019, Legalis.
} 


\section{Sprzedaż ruchomości o wartości historycznej, naukowej lub artystycznej}

W postępowaniu egzekucyjnym $w$ administracji sprzedaż przedmiotów, których dotyczą niniejsze rozważania, reguluje art. 105 \& 2 u.p.e.a. Zgodnie z jego dotychczasową treścią, zajęte przedmioty stanowiące zabytek organ egzekucyjny, w uzgodnieniu z właściwym ze względu na miejsce zajęcia tych przedmiotów wojewódzkim konserwatorem zabytków, a w przypadku materiałów bibliotecznych dyrektorem Biblioteki Narodowej w Warszawie, zgłaszał w celu nabycia państwowej lub samorządowej instytucji kultury lub przedsiębiorcy zajmującemu się obrotem tymi przedmiotami; przy tym - stosownie do § 3 tego artykułu - sprzedaż następowała po cenie oszacowania. Po nowelizacji przepis ten stanowi, że zajętą ruchomość o wartości historycznej, naukowej lub artystycznej organ egzekucyjny sprzedaje po cenie oszacowania państwowej lub samorządowej instytucji kultury wskazanej odpowiednio przez wojewódzkiego konserwatora zabytków lub dyrektora Biblioteki Narodowej w Warszawie (z brzmienia przepisu wynika, że sformułowanie o wskazaniu nabywcy dokonywanym przez dyrektora Biblioteki Narodowej w Warszawie odnosi się do materiałów bibliotecznych). Z dalszej części tego przepisu wynika, że dopiero jeżeli taka sprzedaż nie dojdzie do skutku ${ }^{61}$, organ egzekucyjny stosuje inne sposoby sprzedaży określone w przepisie. Chodzi o sposoby wymienione $w$ art. $105 \S 1$ u.p.e.a.; są to: sprzedaż w drodze licytacji publicznej, sprzedaż po cenie oszacowania podmiotom prowadzącym działalność handlową, przekazanie do sprzedaży podmiotom prowadzącym sprzedaż komisową tego rodzaju ruchomości, sprzedaż w drodze przetargu ofert, sprzedaż z wolnej ręki. Przy tym - zgodnie $z$ art. 107e $\S 1$ zd. pierwsze u.p.e.a. - licytacja publiczna może odbywać się w formie elektronicznej ${ }^{62}$. Artykuł $105 \S 2$ u.p.e.a. nie odsyła natomiast do art. 104a u.p.e.a., regulującego sprzedaż ruchomości przez samego zobowiązanego, na jego wniosek, za zgodą organu egzekucyjnego (taka sprzedaż stanowi nowe rozwiązanie ustawowe, wprowadzone na mocy tej samej nowelizacji).

Do unormowania trybu zarówno przechowywania, jak i sprzedaży zajętych kosztowności ustawa upoważniła ministra właściwego do spraw finansów publicznych (art. 109 § 1 u.p.e.a.).

Natomiast w wypadku, gdy rzecz o wartości historycznej, naukowej lub artystycznej zalicza się do takich rzeczy, których sprzedaż wymaga zezwolenia, koncesji albo jest działalnością regulowaną, to zastosowanie ma - jako bardziej szczegól-

\footnotetext{
${ }^{61}$ W szczególności dana instytucja kultury może nie być zainteresowana nabyciem rzeczy.

62 Na mocy tej samej nowelizacji licytację elektroniczną uregulowano na nowo. Ma ona się odbywać wyłącznie za pośrednictwem systemu teleinformatycznego prowadzonego przez podmiot wybrany przez organ egzekucyjny, który zajął ruchomość (należy przy tym zauważyć, że licytacja ta ma miejsce według regulaminu ustalonego dla portalu, za pośrednictwem którego jest prowadzona); Uzasadnienie projektu, s. $123,124 \mathrm{i} 125$.
} 


\title{
ARTYKUtY
}

Marek Mrówczyński

ny - art. 105 § 5 u.p.e.a. ${ }^{63}$ Oznacza to, że organ egzekucyjny rzecz, o której mowa, przekazuje do sprzedaży podmiotowi posiadającemu takie zezwolenie albo koncesję lub spełniającemu warunki wymagane prawem do wykonywania działalności regulowanej albo sprzedaje ją takiemu podmiotowi. Stosownie do art. 107e § 1 zd. drugie u.p.e.a. wykluczona jest licytacja elektroniczna takiej rzeczy.

Jeżeli chodzi o egzekucję sądową, to według brzmienia art. $866^{2} \S 1$ zd. drugie k.p.c., przedmioty o wartości historycznej lub artystycznej mogą być sprzedane za pośrednictwem przedsiębiorstwa zajmującego się ich obrotem albo państwowemu muzeum, bibliotece, archiwum lub ośrodkowi badań i dokumentacji. W zdaniu trzecim przepis ten stanowi, że odpowiednio należy stosować art. $864^{1}$ k.p.c. Ten ostatni przepis reguluje sprzedaż z wolnej ręki (za zgodą dłużnika z określeniem przez niego minimalnej ceny i przy braku sprzeciwu wierzycieli). W najogólniejszym ujęciu sprzedaż egzekucyjna ruchomości może być licytacyjna albo nielicytacyjna ${ }^{64}$. Sprzedaż z wolnej ręki jest sprzedażą nielicytacyjną i charakteryzuje się przede wszystkim tym, że daje komornikowi możliwość swobodnego wyboru nabywcy ${ }^{65}$.

Przepis art. $866^{2} \S 1$ zd. drugie k.p.c. stwarza trudności interpretacyjne, na co

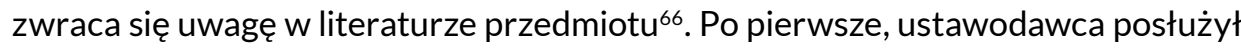
się $w$ nim pewnym uproszczeniem, gdyż w odniesieniu do kręgu podmiotów, do których komornik może wystąpić z ofertą pośrednictwa w sprzedaży lub którym może zaoferować nabycie, nie w każdym z tych wypadków mamy do czynienia z osobą prawną lub jednostką, która nie będąc osobą prawną, posiadałaby zdolność prawną ${ }^{67}$. Po drugie, nie jest jasny sam sens istnienia tego przepisu, tym bardziej że w uzasadnieniu projektu nowelizacji wprowadzającej ten przepis ${ }^{68}$ brak szczegółowych motywów. Wykładnia językowa rozważanego przepisu nie wystarcza do sformułowania jednoznacznych sensownych wniosków, bowiem to, że wymienione w nim podmioty mogą być nabywcami ruchomości, o której mowa - tak, jak i inne podmioty - jest oczywiste i nie wymaga regulacji. Odrzucić należy pogląd, według którego sprzedaż „może nastąpić wyłącznie na rzecz podmiotów wymienionych

\author{
63 Zob. ibidem, s. 113. \\ 64 A. Marciniak, op. cit., s. 202. \\ 65 Zob. S. Cieślak, komentarz do art. 86411, w: J. Jankowski (red.), op. cit.
}

66 Zob. T. Ereciński (red.), Kodeks postępowania cywilnego. Komentarz, t. V: H. Pietrzkowski, Postępowanie egzekucyjne, Wolters Kluwer Polska, Warszawa 2016, s. 432. Szerzej: M. Mrówczyński, Egzekucja sądowa z ruchomości o wartości historycznej lub artystycznej, w: A. Jagielska-Burduk, W. Szafrański (red.), Kultura w praktyce. Zagadnienia prawne, t. 2: Wokół problematyki prawnej zabytków i rynku sztuki, Wydawnictwo Poznańskiego Towarzystwa Przyjaciół Nauk, Poznań 2013, s. 124-127.

67 Przede wszystkim należy zauważyć, że ustawodawca w analizowanym przepisie użył wyrazu „przedsiębiorstwo" w znaczeniu podmiotowym; tak też K. Flaga-Gieruszyńska, komentarz do art. 866², w: A. Zieliński, K. Flaga-Gieruszyńska (red.) op. cit. Poza tym sformułowanie „państwowe muzeum” wyraźnie przeniesione jest z dawnej treści art. 865 § 2 k.p.c. i w ten sposób bez przyczyny pomija się inne muzea, w szczególności samorządowe. Zob. też przypis 14.

68 Druk sejmowy nr 965 Sejmu IV kadencji, http://www.sejm.gov.pl [dostęp: 20.03.2020]. 
Administracyjna i sądowa egzekucja z ruchomości o wartości historycznej... Administrative and judicial execution against movables possessing historical...

w tym przepisie"69. Poglądu tego nie można przyjąć zarówno z tej przyczyny, że w przepisie nie ma wyrazu „wyłącznie” ani „tylko”, jak i dlatego, że tam, gdzie ustawodawca stwarza ograniczenie w tym zakresie, używa sformułowania „komornik sprzedaje" (jak w § $2 \mathrm{i} 3$ artykułu $866^{2}$ i podobnie w art. $866^{1}$ k.p.c.) ${ }^{70}$. To, że w przepisie jest mowa o sprzedaży za pośrednictwem odpowiedniego przedsiębiorstwa, wskazuje, iż sama osoba nabywcy jest obojętna, a celem tego przepisu jest jedynie ułatwienie komornikowi sprzedaży za odpowiednią cenę i stworzenie podstawy do zaliczenia do kosztów postępowania egzekucyjnego kosztów zwracania się przez komornika do tych instytucji z wyżej wymienionymi ofertami.

Tak więc sprzedaż przedmiotów o wartości historycznej lub artystycznej za pośrednictwem przedsiębiorstwa zajmującego się obrotem takimi przedmiotami lub na rzecz instytucji wymienionych w rozważanym przepisie zależy wyłącznie od decyzji komornika, podjętej na podstawie wszechstronnej oceny okoliczności danej sprawy. Komornik może zatem zgłosić podmiotom wymienionym $w$ tym przepisie ofertę sprzedaży przedmiotów za cenę wynikającą z szacunku dokonanego przez biegłego ${ }^{71}$. Podobnie może skorzystać z pośrednictwa, o którym mowa w przepi$s i e^{72}$. Może jednak od razu zdecydować inaczej i wtedy również każdy inny podmiot będzie mógł nabyć zajętą rzecz z wolnej ręki ${ }^{73}$. W ostateczności zostanie zastosowana sprzedaż licytacyjna ${ }^{74}$. Na wniosek wierzyciela - złożony po dokonaniu zajęcia - komornik może zastosować sprzedaż w drodze licytacji elektronicznej ${ }^{75}$. Zakłada się, że ten sposób sprzedaży powinien być najbardziej efektywny ${ }^{76} ; \mathrm{z}$ tym że stosowny wniosek wierzyciela wyłącza licytację tradycyjną, a nie inne rodzaje sprzedaży mające pierwszeństwo w zastosowaniu ${ }^{77}$. Natomiast art. 867 § 4 k.p.c.

69 Tak przyjmuje A. Adamczuk, w: M. Manowska (red.), op. cit., s. 580. Mniej rygorystycznie S. Cieślak, komentarz do art. 866 ${ }^{2}$, w: J. Jankowski (red.), op. cit. oraz M. Michalska-Marciniak, w: A. Marciniak, K. Piasecki (red.), Kodeks postępowania cywilnego, t. III: Komentarz do art. 740-1088, C. H. Beck, Warszawa 2015, s. 545.

70 Tak słusznie H. Pietrzkowski, op. cit., s. 432. Zauważyć też należy różnicę w stosunku do wspomnianego już art. $865 \S 2$ k.p.c. w poprzednim brzmieniu (odpowiednika obecnego art. $866^{2} \S 1$ zd. drugie), w którym użyte było sformułowanie „komornik zgłosi w celu nabycia”.

71 H. Pietrzkowski, op. cit., s. 432.

72 Przedsiębiorstwo, o którego pośrednictwie jest mowa w przepisie, może też samo być nabywcą; M. Uliasz, w: J. Gołaczyński (red.), Kodeks postępowania cywilnego, postępowanie zabezpieczające i egzekucyjne, komentarz, Wolters Kluwer Polska, Warszawa 2012, s. 469.

73 O. Marcewicz, w: A. Jakubecki (red.), Kodeks postępowania cywilnego, komentarz, Lex 2010. Podobnie H. Pietrzkowski, op. cit., s. 432; M. Uliasz, Kodeks postępowania cywilnego, komentarz, C.H. Beck, Warszawa 2008, s. 1256; I. Gil, komentarz do art. 866², w: E. Marszałkowska-Krześ (red.), op. cit.

74 Licytację publiczną regulują art. 867 i n. k.p.c.

75 Por. K. Flaga-Gieruszyńska, komentarz do art. 87911 w: A. Zieliński, K. Flaga-Gieruszyńska (red.), op. cit. Licytację elektroniczną w egzekucji sądowej wprowadzono na mocy ustawy z dnia 10 lipca 2015 r. o zmianie ustawy - Kodeks cywilny, ustawy - Kodeks postępowania cywilnego oraz niektórych innych ustaw, Dz. U. poz. 1311.

76 Por. I. Gil, komentarz do art. 879¹, w: E. Marszałkowska-Krześ (red.), op. cit.

77 Zob. I. Kunicki, Elektroniczna licytacja w sadowym postępowaniu egzekucyjnym, w: A. Marciniak (red.), Elektronizacja sądowego postępowania egzekucyjnego w Polsce, Currenda, Sopot 2015, s. 262-263. 


\section{ARTYKUtY}

Marek Mrówczyński

dopuszczający sprzedaż komisową w egzekucji sądowej z ruchomości został uchylony ustawą z dnia 22 marca 2018 r. o komornikach sądowych ${ }^{78}$.

W odniesieniu do podlegających sprzedaży egzekucyjnej ruchomości ze złota i platyny ustawodawca $w$ art. $866^{2} \S 2 \mathrm{zd}$. drugie k.p.c. wprost wprowadza rygory. Przedmioty ze złota i platyny, które są przedmiotami użytkowymi, mogą być sprzedane $z$ wolnej ręki ${ }^{79}$. Pozostałe przedmioty ze złota i platyny - $w$ tym również niezdatne do użytku - komornik obowiązany jest sprzedać przedsiębiorstwu jubilerskiemu lub innemu zajmującemu się obrotem bądź przerobem metali szlachetnych (zgodnie z odesłaniem - na warunkach z art. 865 k.p.c.); sprzedaż z wolnej ręki jest wyłączona ${ }^{80}$. Niesprzedanie tych ruchomości w sposób określony w art. 865 $\S 2$ k.p.c. otwiera drogę do sprzedaży licytacyjnej ${ }^{81}$.

Jeżeli ruchomość o wartości historycznej lub artystycznej należy do takich, których sprzedaż wymaga zezwolenia, komornik sprzedaje ją za pośrednictwem przedsiębiorstwa posiadającego takie zezwolenie lub sprzedaje ją temu przedsiębiorstwu (art. $866^{1}$ zd. pierwsze k.p.c.) ${ }^{82}$. Zgodnie z art. 867 § 1 k.p.c., licytacja publiczna jest w takich wypadkach wyłączona.

W pozostałym zakresie do sprzedaży egzekucyjnej przedmiotów o wartości historycznej lub artystycznej przepisy o egzekucji z ruchomości stosuje się bez zmian.

\section{Wnioski}

Od wejścia w życie ustawy z dnia 11 września 2019 r., nowelizującej ustawę o postępowaniu egzekucyjnym $w$ administracji, ustawodawca - ani na gruncie przepisów o egzekucji administracyjnej, ani na gruncie przepisów o egzekucji sądowej nie posługuje się pojęciem egzekucji z rzeczy stanowiącej zabytek czy egzekucji z przedmiotu zabytkowego. Niemniej użyte w przepisach normujących egzekucję sformułowanie „przedmiot o wartości historycznej lub artystycznej” oraz pojęcie „ruchomość o wartości historycznej, naukowej lub artystycznej” obejmują swoim zakresem również normatywne pojęcie zabytku.

W uzasadnieniu projektu wskazanej nowelizacji stwierdza się, że zmiana sformułowania "ruchomość stanowiąca zabytek" na sformułowanie "ruchomość o wartości historycznej, naukowej lub artystycznej" ma "charakter dostosowawczy" do przepisów ustawy o ochronie zabytków i opieki nad zabytkami83. W istocie - jak

\footnotetext{
78 Ustawa z dnia 22 marca 2018 r. o komornikach sądowych, tekst jedn. Dz. U. z 2020 r., poz. 121.

79 H. Pietrzkowski, op. cit., s. 429.

80 Ibidem, s. 296; K. Flaga-Gieruszyńska, komentarz do art. 866², w: A. Zieliński, K. Flaga-Gieruszyńska (red.), op. cit.

81 Zob. H. Pietrzkowski, op. cit., s. 432.

82 „Zezwolenie” musi być na gruncie tego przepisu rozumiane szeroko, tj. jako wszelkie rodzaje prawnych ograniczeń obrotu ruchomościami; S. Cieślak, komentarz do art. 866¹, w: J. Jankowski (red.), op. cit. W ten sposób sprowadza się to do rozwiązania takiego, jak w wyżej przytoczonym art. $105 \S 5$ u.p.e.a.

83 Uzasadnienie projektu, s. 101. W uzasadnieniu na tej samej stronie wprost utożsamiono pojęcia zabytku i ruchomości o wartości historycznej, naukowej lub artystycznej.
} 
Administracyjna i sądowa egzekucja z ruchomości o wartości historycznej... Administrative and judicial execution against movables possessing historical...

wynika z przeprowadzonych rozważań - jest przeciwnie: ponieważ pojęcie rzeczy o wartości historycznej, naukowej lub artystycznej jest szersze niż normatywne pojęcie zabytku, w wyniku nowelizacji odrębności zawarte $w$ ustawie o postępowaniu egzekucyjnym w administracji obejmą szerszy zakres rzeczy ruchomych, niż to było do tej pory.

Jednocześnie w efekcie tej zmiany nastąpiło ujednolicenie terminologii z nazewnictwem stosowanym w Kodeksie postępowania cywilnego, choć nie jest to ujednolicenie całkowite. W egzekucji sądowej odrębności dotyczą nie „rzeczy o wartości historycznej, naukowej lub artystycznej”, lecz jedynie „rzeczy o wartości historycznej lub artystycznej".

Co do pozostałych omówionych zmian w ustawie o postępowaniu egzekucyjnym w administracji, to nie mają one charakteru zasadniczego; celem ich jest natomiast przyspieszenie i usprawnienie egzekucji z tego rodzaju ruchomości oraz zapewnienie należytego dozoru nad zajętą ruchomością ${ }^{84}$. Jednocześnie nowa regulacja rozwiązuje trudności powstające w sytuacji, gdy pracownik obsługujący organ egzekucyjny ma wątpliwości co do tego, czy dana rzecz jest „ruchomością o wartości historycznej, naukowej lub artystycznej".

Zarówno w egzekucji administracyjnej, jak i sądowej odrębności w zakresie regulacji oszacowania, dozoru i sprzedaży rozważanych rzeczy w stosunku do unormowań ogólnych zastosowane przez ustawodawcę polegają na wprowadzeniu określonych rygorów dotyczących czynności organu prowadzącego postępowanie egzekucyjne. Więcej tych rygorów - przynajmniej na poziomie unormowań o randze ustawowej - obowiązuje w egzekucji administracyjnej. Jest to bowiem nie tylko konieczność oszacowania rzeczy przez osobę posiadającą wiedzę specjalistyczną, ale też zapewnienie profesjonalnego dozoru nad nią, a przy sprzedaży - pierwszeństwo nabycia przez instytucję kultury.

Celem istnienia tych rygorów nie jest ochrona rzeczy, o których mowa - w tym zabytków - przed egzekucją ${ }^{85}$. Ani w egzekucji administracyjnej, ani w egzekucji sądowej ustawodawca nie wyłącza w stosunku do tych ruchomości zwykłych sposobów sprzedaży, tzn. możliwa jest sprzedaż na zasadach ogólnych, w tym nawet w drodze licytacji elektronicznej, która z założenia powinna być najbardziej efektywna (przy tym należy zwrócić uwagę na istotną nowelizację przepisów o tej licytacji w ramach egzekucji administracyjnej).

Co innego, jeżeli sprzedaż dotyczy kosztowności. Należy bowiem mieć na uwadze, że przepisy regulujące egzekucję administracyjną skierowaną do kosztowności oraz przepisy regulujące egzekucję sądową skierowaną do przedmiotów ze złota lub platyny, wprowadzające szczególny reżim sprzedaży, są bardziej szczególne w stosunku do przepisów odnoszących się do egzekucji z ruchomości o war-

\footnotetext{
84 Ibidem.

85 Można uznać, że wystarczającym motywem istnienia rozważanych regulacji szczególnych jest szczególne traktowanie tych przedmiotów na rynku, tj. przede wszystkim wpływ wartości historycznej, naukowej czy artystycznej (a zwłaszcza tej ostatniej) na zwiększenie się ceny rynkowej.
} 


\section{ARTYKUtY}

Marek Mrówczyński

tości historycznej, naukowej lub artystycznej. Podobnie jest w sytuacji, gdy zajęte ruchomości należą jednocześnie do takich, których sprzedaż wymaga zezwolenia, koncesji lub jest działalnością regulowaną.

\section{Bibliografia}

Adamczuk A., w: M. Manowska (red.), Kodeks postępowania cywilnego. Komentarz, t. 2: art. 506-1217, Lexis Nexis, Warszawa 2011.

Antoniak P., w: M. Cherka (red.), Ustawa o ochronie zabytków i opiece nad zabytkami, komentarz, Lex 2010.

Chorąży K., w: K. Chorąży, W. Taras, A. Wróbel, Postępowanie administracyjne, egzekucyjne i sądowoadministracyjne, Wolters Kluwer Polska, Warszawa 2009.

Cieślak S., komentarz do art. 864¹, w: J. Jankowski (red.), Kodeks postępowania cywilnego, t. 2: Komentarz, art. 730-1217, Warszawa 2019, Legalis.

Cieślak S., komentarz do art. 866², w: J. Jankowski (red.), Kodeks postępowania cywilnego, t. 2: Komentarz, art. 730-1217, Warszawa 2019, Legalis.

Druk sejmowy nr 965 Sejmu IV kadencji, http://www.sejm.gov.pl [dostęp: 20.03.2020].

Ereciński T. (red.), Kodeks postępowania cywilnego. Komentarz, t. V: H. Pietrzkowski, Postępowanie egzekucyjne, Wolters Kluwer Polska, Warszawa 2016.

Flaga-Gieruszyńska K., komentarz do art. 866², w: A. Zieliński, K. Flaga-Gieruszyńska (red.), Kodeks postępowania cywilnego. Komentarz, Warszawa 2019, Legalis.

Flaga-Gieruszyńska K., komentarz do art. 879¹ , w: A. Zieliński, K. Flaga-Gieruszyńska (red.), Kodeks postępowania cywilnego. Komentarz, Warszawa 2019, Legalis.

Gaweł Ł., Dziedzictwo kulturowe - ustalenia podstawowe, w: A. Jagielska-Burduk (red.), Mechanizmy prawne zarządzania dziedzictwem kultury, Wydawnictwo Uniwersytetu Gdańskiego, Wolters Kluwer, Gdańsk-Warszawa 2017.

Gil I., komentarz do art. 853, w: E. Marszałkowska-Krześ (red.), Kodeks postępowania cywilnego. Komentarz, Warszawa 2019, Legalis.

Gil I., komentarz do art. 866², w: E. Marszałkowska-Krześ (red.), Kodeks postępowania cywilnego. Komentarz, Warszawa 2019, Legalis.

Gil I., komentarz do art. 879¹ , w: E. Marszałkowska-Krześ (red.), Kodeks postępowania cywilnego. Komentarz, Warszawa 2019, Legalis.

Gwardzińska Ż., Egzekucja nadzoru konserwatorskiego, Wydawnictwo Uniwersytetu Gdańskiego, Gdańsk 2019.

Hauser R., komentarz do art. 105, w: R. Hauser, A. Skoczylas (red.), Postępowanie egzekucyjne w administracji. Komentarz, Warszawa 2018, Legalis.

Jagielska-Burduk A., Zabytek ruchomy, Wolters Kluwer Polska, Warszawa 2011.

Jędrzejewski T., Masternak M., Rączka P., Administracyjne postępowanie egzekucyjne, TNOiK, Toruń 2020.

Klat-Wertelecka L., Niedopuszczalność egzekucji administracyjnej, Wydawnictwo Uniwersytetu Wrocławskiego, Wrocław 2009.

Kozińska J., Stec P., Odpowiedzialność za wady dzieła sztuki po nowelizacji Kodeksu cywilnego, „Santander Art and Culture Law Review” 2015, nr 1. 
Administracyjna i sądowa egzekucja z ruchomości o wartości historycznej... Administrative and judicial execution against movables possessing historical...

Kunicki I., Elektroniczna licytacja w sądowym postępowaniu egzekucyjnym, w: A. Marciniak (red.), Elektronizacja sądowego postępowania egzekucyjnego w Polsce, Currenda, Sopot 2015.

Lipińska J., Biegły w postępowaniu egzekucyjnym (część druga). Zagadnienia szczegółowe, „Przegląd Prawa Egzekucyjnego" 2018, nr 1.

Lipińska J., Biegły w postępowaniu egzekucyjnym. Zagadnienia ogólne (część pierwsza), „Przegląd Prawa Egzekucyjnego" 2017, nr 10.

Marcewicz O., w: A. Jakubecki (red.), Kodeks postępowania cywilnego, komentarz, Lex 2010.

Marciniak A., Postępowanie egzekucyjne w sprawach cywilnych, Lexis Nexis, Warszawa 2005.

Merchel Z., Ruchomość jako przedmiot egzekucji. Postępowanie, wzory pism i orzeczeń, Currenda, Sopot 2006.

Merchel Z., w: Egzekucja sądowa w Polsce, pod kier. Z. Szczurka, Currenda, Sopot 2007.

Michalska-Marciniak M., w: A. Marciniak, K. Piasecki (red.), Kodeks postępowania cywilnego, t. III: Komentarz do art. 740-1088, C.H. Beck, Warszawa 2015.

Możyłowski P., Zasady ogólne administracyjnego postępowania egzekucyjnego, „Studia Prawnicze KUL" 2016, nr 1.

Mrówczyński M., Egzekucja sądowa z ruchomości o wartości historycznej lub artystycznej, w: A. Jagielska-Burduk, W. Szafrański (red.), Kultura w praktyce. Zagadnienia prawne, t. 2: Wokół problematyki prawnej zabytków i rynku sztuki, Wydawnictwo Poznańskiego Towarzystwa Przyjaciół Nauk, Poznań 2013.

Mularski K., O skarbach de lege lata i de lege ferenda, „Monitor Prawniczy” 2009, nr 12.

Piątek W., Skoczylas A., Postępowanie egzekucyjne w administracji, w: Hauser R. (red.), System Prawa Administracyjnego, t. 9, Hauser R., Niewiadomski Z., Wróbel A. (red.), Prawo procesowe administracyjne, Warszawa 2020, Legalis.

Pruszyński J., Stan i potrzeby regulacji prawnej ochrony zabytków w Polsce, „Ochrona Zabytków" 1996, nr 3.

Przybysz P., Egzekucja administracyjna, Dom Wydawniczy ABC, Warszawa 1999.

Radwański Z., Prawo cywilne - część ogólna, C.H. Beck, Warszawa 2007.

Rozporządzenie Ministra Kultury z dnia 10 maja 2004 r. w sprawie rzeczoznawców Ministra Kultury w zakresie opieki nad zabytkami, Dz. U. Nr 124, poz. 1302.

Rozporządzenie Ministra Sprawiedliwości z dnia 16 sierpnia 2016 r. w sprawie oddawania zajętych ruchomości do depozytu sądowego albo na przechowanie właściwym instytucjom, Dz. U. poz. 1326.

Stec P., Kolekcja jako przedmiot obrotu cywilnoprawnego, w: P. Stec, P.P. Maniurka (red.), Kolekcje i zbiory muzealne. Problematyka prawna, Wydawnictwo i Drukarnia Świętego Krzyża, Opole 2015.

Stelmachowski A., w: Z. Radwański (red.), System Prawa Prywatnego, t. 3: T. Dybowski (red.), Prawo rzeczowe, C.H. Beck, Warszawa 2007.

Szubiakowski M., w: M. Wierzbowski (red.), Postępowanie administracyjne - ogólne, podatkowe, egzekucyjne i przed sq̨dami administracyjnymi, C.H. Beck, Warszawa 2008.

Uchwała Sądu Najwyższego z dnia 17 września 1969 r., sygn. akt III CZP 68/69, OSNC 1970, z. 2, poz. 29.

Uchwała Sądu Najwyższego z dnia 9 grudnia 1986 r., sygn. akt III CZP 61/86, OSNCP 1987, z. 9, poz. 129. 


\section{ARTYKUtY}

Marek Mrówczyński

Uliasz M., Kodeks postępowania cywilnego, komentarz, C.H. Beck, Warszawa 2008.

Uliasz M., w: J. Gołaczyński (red.), Kodeks postępowania cywilnego, postępowanie zabezpieczające i egzekucyjne, komentarz, Wolters Kluwer Polska, Warszawa 2012.

Ustawa o ochronie dóbr kultury z dnia 15 lutego 1962 r., tekst jedn. Dz. U. z 1999 r. Nr 98, poz. 1150 ze zm.

Ustawa z dnia 17 listopada 1964 r. Kodeks cywilny, tekst jedn. Dz. U. z 2019 r., poz. 1460 ze $z m$.

Ustawa z dnia 17 czerwca 1966 r. o postępowaniu egzekucyjnym w administracji, tekst jedn. Dz. U. z 2019 r., poz. 1438 ze zm.

Ustawa z dnia 25 października 1991 r. o organizowaniu i prowadzeniu działalności kulturalnej, tekst jedn. Dz. U. z 2020 r., poz. 194.

Ustawa z dnia 21 listopada 1996 r. o muzeach, tekst jedn. Dz. U. z 2019 r., poz. 917 ze zm.

Ustawa z dnia 27 czerwca 1997 r. o bibliotekach, tekst jedn. Dz. U. z 2019 r., poz. 1479.

Ustawa z dnia 29 sierpnia 1997 r. o Narodowym Banku Polskim, tekst jedn. Dz. U. z 2019 r., poz. 1810.

Ustawa z dnia 6 września 2001 r. o zmianie ustawy o postępowaniu egzekucyjnym w administracji oraz niektórych innych ustaw, Dz. U. Nr 125, poz. 1368.

Ustawa z dnia 23 lipca 2003 r. o ochronie zabytków i opiece nad zabytkami, tekst. jedn. Dz. U. z 2018 r., poz. 2067 ze zm.

Ustawa z dnia 2 lipca 2004 r. o zmianie ustawy Kodeks postępowania cywilnego oraz niektórych innych ustaw, Dz. U. Nr 172, poz. 1804.

Ustawa z dnia 18 marca 2010 r. o zmianie ustawy o ochronie zabytków i opiece nad zabytkami oraz o zmianie niektórych innych ustaw, Dz. U. Nr 75, poz.474.

Ustawa z dnia 20 lutego 2015 r. o rzeczach znalezionych, Dz. U. poz. 397.

Ustawa z dnia 10 lipca 2015 r. o zmianie ustawy - Kodeks cywilny, ustawy - Kodeks postępowania cywilnego oraz niektórych innych ustaw, Dz. U. poz. 1311.

Ustawa z dnia 22 marca 2018 r. o komornikach sądowych, tekst jedn. Dz. U. z 2020 r., poz. 121.

Ustawa z dnia 11 września 2019 r. o zmianie ustawy o postępowaniu egzekucyjnym w administracji oraz niektórych innych ustaw, Dz. U. poz. 2070.

Uzasadnienie projektu ustawy z dnia 11 września 2019 r. o zmianie ustawy o postępowaniu egzekucyjnym w administracji oraz niektórych innych ustaw, Druk sejmowy Sejmu VIII kadencji nr 3753, s. 100, http://www.sejm.gov.pl.

Woźniak Z., Egzekucja świadczeń pieniężnych, w: J. Gołaczyński (red.), Wybrane zagadnienia egzekucji sądowej, Wolters Kluwer Polska, Warszawa 2008.

Zajęcki M., Definiowanie pojęć podstawowych prawa kultury w kontekście zasad wykładni prawa polskiego, w: A. Jagielska-Burduk, W. Szafrański (red.), Kultura w praktyce. Zagadnienia prawne, Wydawnictwo Poznańskiego Towarzystwa Przyjaciół Nauk, Poznań 2012.

Zalasińska K., Muzealia, zbiory, eksponaty, kolekcja muzealna oraz zasoby muzeum - pojęcia podstawowe w muzealnictwie, w: P. Stec, P.P. Maniurka (red.), Kolekcje i zbiory muzealne. Problematyka prawna, Wydawnictwo i Drukarnia Świętego Krzyża, Opole 2015.

Zeidler K., Prawo ochrony dziedzictwa kultury, Wolters Kluwer Polska, Warszawa 2007.

Zeidler K., Zabytki. Prawo i praktyka, Wydawnictwo Uniwersytetu Gdańskiego, Wolters Kluwer, Gdańsk-Warszawa 2017. 